\title{
Depression level and quality of life in ovarian cancer patients in Zainoel Abidin Hospital, Banda Aceh
}

\author{
Akmalia $\mathbf{G}^{1}$ Riswan $\mathbf{M}^{2}$, Andalas $\mathbf{M}^{3}$ \\ 'Medical Doctor Program, ${ }^{2}$ Internal Medicine Department, ${ }^{3}$ Obstetric and Gynecology Department, \\ Faculty of Medicine, Syiah Kuala University, Zainoel Abidin Hospital, Banda Aceh, Indonesia
}

\section{ABSTRAK}

Tujuan: mengetahui hubungan tingkat depresi dengan kualitas hidup pasien kanker ovarium yang sedang menjalani kemoterapi di RSUDZA Banda Aceh.

Bahan dan Metode: Penelitian ini adalah analitik observasional dengan rancangan cross sectional. Pengambilan sampel menggunakan teknik accidental sampling dengan jumlah sampel sebanyak 30 orang. Penilaian derajat depresi menggunakan kuesioner BDIII dan untuk kualitas hidup menggunakan kuesioner EORTC QLQ-C30. Data selanjutnya dianalisis dengan uji statistik Spearman Correlation.

Hasil: sebagian besar pasien mengalami gejala tidak depresi $(53,3 \%)$, dan memiliki kualitas hidup baik $(56,7 \%)$. Kemudian kasus terendah berada pada pasien yang mengalami depresi berat $(6,7 \%)$ dan kualitas hidup buruk (16,7\%). Analisa data diperoleh nilai $\mathrm{p}=0,000(\mathrm{p} \unlhd), 05)$.

Simpulan: terdapat hubungan yang signifikan antara tingkat depresi dengan kualitas hidup pasien kanker ovarium yang sedang menjalani kemoterapi di RSUDZA Banda Aceh. (MOG 2017;25:16-20)

\begin{abstract}
Objectives: to determine the relationship between depression and quality of life in ovarian cancer patients who are undergoing chemotherapy in RSUDZA Banda Aceh.

Materials and Methods: This study was an analytical observational study with cross-sectional design approach. The samples were taken by using accidental sampling with total of respondents are 30 patients. Depression level was assessed by using the BDI-II questionnaire and quality of life was assessed by using the EORTC QLQ-C30 questionnaire. Then, data were analyzed by using Spearman's Correlation test.

Results: The most of the cases were no depression $(53,3 \%)$, and good quality of life $(56,7 \%)$. The lowest cases were patients with severe depression $(6,7 \%)$, and poor quality of life $(16,7 \%)$. The results of data analysis obtained $\mathrm{p}$ value $=0.000(\mathrm{p} \unlhd), 05)$. Conclusion: there is a significant relationship between depression and quality of life in ovarian cancer patients who are undergoing chemotherapy in RSUDZA Banda Aceh. (MOG 2017;25: 16-20)
\end{abstract}

Keywords: Depression level; quality of life; ovarian cancer

Kata kunci: Tingkat depresi; kualitas hidup; kanker ovarium

Correspondence: Ghina Akmalia, Jln.T.Iskandar Lr.Mawar no.56 Desa Lamglumpang Ulee Kareng Banda Aceh 23117, 081360391091, email: iginakmalia@gmail.com

\section{INTRODUCTION}

Ovarian cancer is a type of malignancy with high morbidity and mortality in women and the forth leading cause of cancer deaths in women. ${ }^{1}$ Based on the amount of the cases with about 26,000 cases per year, ovarian cancer is the leading cause of gynecological cancer death in the United States, about 14,500 deaths were reported every year. ${ }^{2}$ Ovarian cancer had 239,000 new cases diagnosed worldwide in 2012, showing the highest incidence rates in Central and Eastern Europe and the lowest in West Africa. ${ }^{3}$ In 2013, there were 7,284 new cases of ovarian cancer in the UK. The incidence rate shows there are 22 new cases of ovarian cancer for every 100,000 women in the UK. ${ }^{4}$

The incidence of ovarian cancer in each country varies greatly, the highest incidence was found in industrialized countries in Europe and North America. Countries like Asia and Africa generally have a low incidence of ovarian cancer. The incidence of ovarian cancer at age 45-59 years was 16.4 cases per 100,000 , the frequency increased in older age. At the age of 60 the incidence increased more than twice, which is about 40 cases per 100,000 with the highest incidence of 61 cases per 100,000 at the age of $80-84$ years. ${ }^{5}$ The incidence of ovarian cancer in Indonesia is not known for certain. However, based on the data from Dharmais Cancer Hospital Jakarta in 2013, ovarian cancer ranked forth in the cause of cancer in women, with the number of patients were 134 people, and 46 were died. ${ }^{6}$ At the Regional General Hospital dr. Zainoel Abidin Banda Aceh in 2013, ovarian cancer ranked second in the cause of gynecologic cancer in women after cervical cancer, with 74 patients. Meanwhile, in 2015 there were reported 100 people with ovarian cancer who underwent chemotherapy at RSUDZA. ${ }^{7}$

The cancer that causes the most death in women is ovarian cancer, so it is often referred as a silent killer because it does not display a typical complaint (asymptomatic), the patient usually comes already with an advanced stage. The most common type of ovarian cancer found is epithelial type (85\%-90\%), this type of cancer generally occurs at the age above 50 years, the incidence rate continues to increase with age. ${ }^{5}$ 
Ovarian cancer is a very aggressive disease because of its very low survival rates and high recurrence rates. Usually, the disease is detected at an advanced stage, the 5-year survival rate in all stages is about $46 \%$, and $31 \%$ at advanced stage. The difficulty to accept the diagnosis of aggressive and life-threatening diseases increases the patient's life pressure. In fact, the disease is regarded as a trauma for the sufferer and has a strong psychological impact for themselves as well as the quality of their life. ${ }^{1,8}$

A study showed that patients with ovarian cancer provide a large proportion of psychological disorders, such as anxiety, depression, and Post Traumatic Stress Disorder (PTSD). ${ }^{8}$ Qualitative studies and quality of life indicated significant distress, as well as worsening of physical activity, work, social, family, and sexual function in ovarian cancer patients. ${ }^{10}$

In a study by Gonçalves entitled Quality of Life in Ovarian Cancer Survivors, a cohort study was conducted to measure psychological disorders, such as anxiety and depression, neuroticism, and coping strategies to control unwanted thoughts in ovarian cancer patients. Measurements were performed at the same time in patients receiving chemotherapy, mid, late, and 3 months post-chemotherapy. The results show that there are 3 patterns of anxiety and depression over time: never at all, intermittent, and persistent (persistent). Most women had intermittent anxiety (52\%), while 38\% of depressed cases were at some point in time, and some women had persistent anxiety (22\%), and persistent depression $(6 \%) .^{11}$

Another study strenghtened, in patients who have been declared free of ovarian cancer, the quality of lifes were relatively good, especially in terms of physical activity. However, patients reported emotional problems such as distress (40\%), anxious about Ca125 test results (54\%), fear of recurrence (56\%), and PTSD (26\%).

Based on the description above, there is no data about psychological disorders of patients with ovarian cancer after undergoing chemotherapy in Indonesia, therefore the authors interested to analyze the relationship between depression levels with quality of life in ovarian cancer patients who are undergoing chemotherapy at the Regional General Hospital dr. Zainoel Abidin.

\section{MATERIALS AND METHODS}

This research is an observational analytic research with cross sectional design. Research data was collected in the Mamplam III (Kemoterapi) and Serune III wards at RSUDZA Banda Aceh from September to December
2016. The population in this study were all ovarian cancer patients who underwent chemotherapy in the Mamplam III ward RSUDZA in the last year which amounted to 100 people (2015). The samples in this study were ovarian cancer patients who met inclusion and exclusion criteria. Sampling technique in this research was non probability sampling using accidental sampling method.

The instruments used in this study were BDI-II depression questionnaire and valid QOSQ-C30 quality of life questionnaire. Data retrieval was done by guided interview. Data analysis was done in univariate and bivariate analysis. Univariate analysis was performed to know the frequency distribution of each variable and bivariate analysis using Spearman's correlation test was done to test the hypothesis.

\section{RESULTS AND DISCUSSION}

The data collected in this research from September to December 2016 consist of 30 samples.

Based on Table 1 it can be explained that ovarian cancer patients were most prevalent in the 36-45 age group with 12 people $(40.0 \%)$, had married with 24 people $(80.0 \%)$, nullipara parity 13 people $(43.3 \%)$, no previous cancer history in family with 26 people $(86,7 \%)$, sixth chemotherapy cycle in 14 people $(46,7 \%)$, and stage II counted in 15 people $(50,0 \%)$.

Table 1. Frequency distribution of respondents' characteristics

\begin{tabular}{lll}
\hline Respondents' characteristics & Frequency (n) & $\begin{array}{l}\text { Percentage } \\
(\%)\end{array}$ \\
\hline Age & & \\
17-25 years old & 2 & 6.7 \\
26-35 years old & 2 & 6.7 \\
36-45 years old & 12 & 40.0 \\
$46-55$ years old & 11 & 36.7 \\
56-65 years old & 2 & 6.7 \\
$\quad$ 65 years old & 1 & 3.3 \\
Status & & \\
Married & 24 & 80.0 \\
$\quad$ Single & 6 & 20.0 \\
Parity & & \\
$\quad$ Nullipara & 13 & 43.3 \\
Primipara & 3 & 10.0 \\
$\quad$ Multipara & 10 & 33.3 \\
$\quad$ Grandemultipara & 4 & 13.3 \\
Family History & & \\
Positive & 4 & 13.3 \\
$\quad$ Negative & 26 & 86.7 \\
Chemotherapy cycle & & \\
First cycle & 7 & 23.3 \\
Third cycle & 3 & 10.0
\end{tabular}




\begin{tabular}{cll} 
Forth cycle & 4 & 13.3 \\
Sixth cycle & 14 & 46.7 \\
Ninth cycle & 2 & 6.7 \\
Stadium & & \\
Stadium I & 2 & 6,7 \\
Stadium II & 15 & 50,0 \\
Stadium III & 10 & 33,3 \\
Stadium IV & 3 & 10,0 \\
\hline
\end{tabular}

Table 2. Depression level distribution

\begin{tabular}{lcc}
\hline Depression level & Frequency $(\mathrm{n})$ & Percentage $(\%)$ \\
\hline None & 16 & 53.3 \\
Mild & 5 & 16.7 \\
Moderate & 7 & 23.3 \\
Severe & 2 & 6.7 \\
Total & 30 & 100.0 \\
\hline
\end{tabular}

Based on Table 2 it can be explained that ovarian cancer patients were mostly found in a state of no depression with 16 people $(53.3 \%)$.

Table 3. Quality of life distribution

\begin{tabular}{lcc}
\hline Quality of Life & Frequency $(\mathrm{n})$ & Percentage $(\%)$ \\
\hline Poor & 5 & 16.7 \\
Moderate & 8 & 26.7 \\
Good & 17 & 56.7 \\
Total & 30 & 100.0 \\
\hline
\end{tabular}

Based on Table 3 it can be explained that ovarian cancer patients were mostly found in good quality of life with 17 people $(56.7 \%)$.

Ovarian cancer patients mostly had non-depressive symptoms with 16 people $(53.3 \%)$ and tend to have a good quality of life with 15 people $(93.8 \%)$. While patients with severe depression as many as 2 people $(6.7 \%)$ tend to have a poor and moderate quality of life 1 person each $(50.0 \%)$. Based on the results of the analysis using Spearman Correllation test, 0.000 probability was obtained (p $₫), 05$ ) so that $\mathrm{H} 0$ was rejected, it shows that there is significant relation between depression level with quality of life in ovarium cancer patient. Then $r$ was counted at correlation rank valued $-0,834$ which shows very strong relationship between depression level with quality of life in ovarian cancer patient, and negative sign indicates the opposite direction between the two variables, the higher the depression level then the quality of life will get worse.

From 30 samples, most of them were in the age group of $36-45$ years old, 12 people $(40.0 \%)$ and followed by the age group of $46-55$ years old, 11 people $(36.7 \%)$. The study of Perbowo et al found that incidence increased with age, 15 new cases per 100,000 population per year were estimated in women aged 40-44 years old. ${ }^{12}$

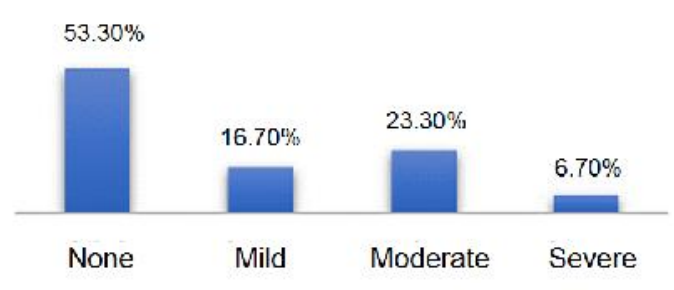

Figure 1. Depression level distribution

Based on marital status, 24 people $(80.0 \%)$ were married. This is in accordance with the research of Kim et al. Who conducted a study on 73 patients with ovarian cancer, and found 70 patients were married $(95.9 \%)$. Most of the subjects' parity was nullipara as many as 11 people (44.0\%). This is consistent with Purdie et al. which stated that nullipara has $6 \%$ higher risk for ovarian cancer, this is because nullipara has higher ovulation cycle than multiparas. ${ }^{14}$

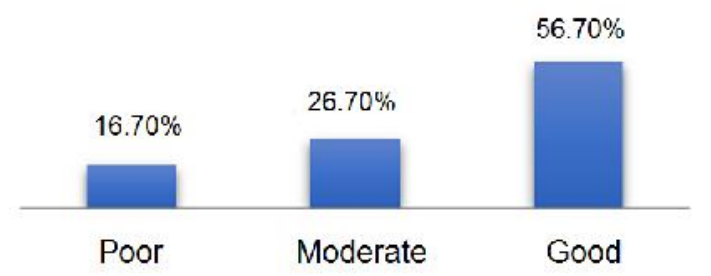

Figure 2. Quality of life distribution

Based on family history, 26 people $(86.7 \%)$ had no family with previous cancer history. This is in accordance with Sun et al. stating that most cases of ovarian cancer had no family with a history of cancer, but $10 \%$ of cases were considered hereditary, and the risk increased by $7 \%$ in women with two first-degree relatives who have a history of cancer. ${ }^{15}$

In this study, the highest stage was stadium II as many as 15 people $(50.0 \%)$ and followed by stage III as many as 10 people $(33.3 \%)$. This is consistent with the theory that, ovarian cancer is often referred as a silent killer because it does not display a typical complaint (asymptomatic) so that ordinary patients come already with an advanced stage.

Based on the symptoms of depression, ovarian cancer patients were most commonly found in the nondepressed condition, $16(53.3 \%)$ and $14(46.7 \%)$ are in a mild to severe depression. This is consistent with the study of Bevers et al. Which conducted a study on 246 patients with ovarian cancer, they found 48 patients 
$(21.0 \%)$ were in a state of depression, and $25 \%$ experienced anxiety. ${ }^{16}$

Based on the quality of life, ovarian cancer patients were mostly found in good quality of life as many as 17 people $(56.7 \%)$. This is consistent with Matulonis et al. Who reported ovarian cancer patients who had recovered generally had a good quality of life. ${ }^{17}$ In the research of Teng et al. who conducted a study on 102 ovarian cancer patients, found that clinical factors such as age, stadium, histology results had no significant relationship to the quality of life of patients. However, anxiety and fatigue were the categories of distress with the highest value. It is concluded that psychological factors have a greater impact on the quality of life than physical symptoms. ${ }^{18}$ This is also in line with the theory stated by Halim et al that quality of life is a multidimensional concept that is highly dependent on how the patients judges, views, and responds to their conditions and situations related to all the effects of the treatment. So the quality of life plays very big role in the motivation of fighting power, survival index of cancer patients to survive and improve his life until finally healed. ${ }^{19}$

Sutrisno and colleagues conducted a study on nonHodgkin's lymphoma cancer patients who underwent chemotherapy at Sanglah Hospital Denpasar, using the EORTC QLQ-C30 questionnaire, there were 5 people with good quality of life $(50.0 \%)$, moderate 3 people $(30.0 \%)$, and poor 2 people $(20.0 \%) .{ }^{20}$ However, it was different from Dehkordi et al. who conducted a study on 200 cancer patients using the EORTC QLQ-C30, majority of the sample was found to be in moderate quality of life with 132 people $(66.0 \%)$, followed by good quality of life 46 people $(23.0 \%)$, and poor 22 people $(11 \%)$. The study found that age, sex, marital status, duration of illness, economic conditions, and occupation did not have a significant relationship to the quality of life of patients. ${ }^{21}$

The result of statistical test showed the correlation between depression level and quality of life in ovarian cancer patients in RSUDZA Banda Aceh with probability $0.000(\mathrm{p} \unlhd, 05)$. This showed that there is a significant relationship between depression level and quality of life in patients with ovarian cancer, the higher the level of depression, the quality of life will get worse. This is consistent with the study of Sood et al. Which discusses the effects of stress hormones that can invade ovarian cancer. The data suggested that certain concentrations of norepinephrine and epinephrine can significantly increase the capacity of ovarian tumor cells to attack the extracellular matrix. This effect is mediated through h-adrenergic receptors in cancer cells that can increase the production of MMP-2 and MMP-9. MMP expression changes facilitate penetration of ovarian cancer cells in the extracellular matrix. In summary, the results of this study suggests that stress hormones can directly increase the invasive potential of ovarian cancer cells through enhancing h-adrenergic regulation of MMP-2 and MMP-9. In association with previous studies that demonstrate $\mathrm{h}$-adrenergic regulation of other molecular processes involved in metastatic cascades, showed that the physio-logical activity of catecholamines may represent new targets for adjuvant therapy that serves to block metastatic processes during and after primary therapy. So understanding the influence of neuroendocrine on the growth and development of cancer can be a strategy to prevent cancer. ${ }^{22}$

The above explanation is in line with the research of Smith et al. Which stated that dopamine can significantly reduce the growth of ovarian cancer cells by inhibiting angiogenesis processes and stimulating tumor cell apoptosis. Dopamine is also proven to block the effects of chronic stress stimulation on cancer growth Dopamine, via DR2, blocks VEGF which is a strong angiogenic factor. VEGF activation increases the proliferation and migration of endothelial cells that will increase the formation of new blood vessels and increase the permeability of blood vessels. VEGF also inhibits the process of apoptosis of new blood vessels that are hyperpermeable. VEGF expression is higher in ovarian cancer than in normal ovarian tissue or benign ovarian neoplasms.

Increased VEGF expression in either the cytosolic fraction of ovarian cancer or serum VEGF levels in preoperative serum is associated with advanced stage or poor resistance. Even in early-stage patients, patients with increased VEGF expression and preoperative serum VEGF levels are associated with a high risk of disease recurrence and worsening. Paley's research showed that increased VEGF expression is a poor prognostic factor compared to other risk factors. In women with advanced cancer, high serum VEGF levels have been shown to be associated with progressive disease course and a risk factor for ascites, increased metastatic events, suboptimal debulking of tumors and decreased survival. A strong association between tumor angiogenesis, serum expression and serum VEGF levels and clinical outcomes in ovarian cancer makes the VEGF pathway as target therapy. ${ }^{23,24}$

\section{CONCLUSION}

Depression level and quality of life correlated significantly in patients with ovarian cancer at Zainoel Abidin Hospital, Banda Aceh. 


\section{REFERENCES}

1. Siegel R, Naishadham D, Jemal A. Cancer Statistics. CA: A Cancer Journal for Clinicians. 2012; 62:5.

2. Gupta D, Braun DP, Staren ED, Markman M. Longitudinal health-related quality of life assessment: Implications for prognosis in ovarian cancer. Journal of Ovarian Research 2013;6-17.

3. Ferlay J, Soerjomataram I, Ervik M, et al. GLOBOCAN 2012 v1.0, Cancer Incidence and Mortality Worldwide: IARC CancerBase No. 11. [serial on the Internet]; 2013. [cited 2016 March 22]. Lyon, France: International Agency for Research on Cancer. Available from: http:// globocan.iarc.fr

4. Cancer Research UK. Ovarian cancer incidence statistics. [serial on the Internet]; 2016. [cited 2016 March 22]. Available from: http://www.cancer researchuk.org/health-professional/cancerstatistics/statistics-by-cancer-type/ovariancancer/incidence\#heading-Zero

5. Trihandini I, Nurrika D. Analisis ketahanan hidup lima tahun penderita kanker ovarium epithelial di Rumah Sakit Kanker Dharmais Jakarta. Jurnal Kesehatan Masyarakat Nasional. 2010;5:140.

6. Kementerian Kesehatan RI. InfoDATIN Pusat Data dan Informasi Kementerian Kesehatan RI. Jakarta; 2015;5.

7. RSUDZA. Rekam Medik Ruang Rawat Inap Serune 3 dan Mamplam 3. Banda Aceh; 2015.

8. Gonçalves V, Jayson G, Tarrier NA. Longitudinal investigation of posttraumatic stress disorder in patients with ovarian cancer. Journal of Psychosomatic Research 2011;70(5):422-31.

9. Hess LM, Stehman FB. State of the science in ovarian cancer quality of life research: a systematic review. International Journal of Gynecological Cancer 2012;22(7);1273-80.

10. Chase DM, Wenzel L. Health-related quality of life in ovarian cancer patients and its impact on clinical management. Expert Review of Pharmaco-economics and Outcomes Research. 2011;11(4): 421-31.

11. Gonçalves, V. Quality of life in ovarian cancer survivors. Journal Research and Networks in Health 2015;2-6.

12. Perbowo P, Askandar B, Sunjoto, Soebadi RD, Basori A. Perbandingan Kejadian Neutropeni dan Neuropati Perifer Akibat Kemoterapi Adjuvan
Paclitaxel - Carboplatin antara Paclitaxel Infus 3 Jam dengan Paclitaxel Infus 24 Jam pada Penderita Kanker Ovarium Stadium I-IV. Majalah Obstetri dan Ginekologi 2008;16:108-9.

13. Kim SI, Lee Y, Lim MC, et al. Quality of life and sexuality comparison between sexually active ovarian cancer survivors and healthy women. Journal of Gynecologic Oncology 2015;148-54.

14. Purdie DM, Bain CJ, Siskind V, et al. Ovulation and risk of epithelial ovarian cancer. Int J Cancer. 2003;104(2):228-32.

15. Sun CC, Ramirez PT, Bodurka DC. Quality of life for patients with epithelial ovarian cancer. Nature Clinical Practice Oncology 2007;4(1):18-29.

16. Bevers DB, Engquisth KB, Carmack CL, Fitzgerald MA, Wolf JK, et al. Depression, Anxiety, and Quality of Life in Patients with Epihelial Ovarian Cancer. Gynecologic Oncology. 2002;78(3):302-8.

17. Matulonis UA, Kornblith A, Lee H, et al. Longterm adjusment of early-stage ovarian cancer survivors. International Journal of Gynecological Cancer 2008;18(6):1183-93.

18. Teng FF, Kalloger SE, Brotto L, McAlpine JN. Detereminants of quality of life in ovarian cancer survivors: a pilot study. Journal of Obstetrics and Gynecology Canada 2014;36(8):708-15.

19. Halim, Surjaningsih M. Efek terapi terhadap quality of life penderita kanker ginekologi. Tesis. Jakarta: Universitas Atma Jaya, Fakultas Psikologi; 2004.

20. Sutrisno H, Dharmayuda TG, Rena RA. Gambaran kualitas hidup pasien kanker limfoma non hodgkin yang dirawat di RSUP Sanglah Denpasar. Jurnal Penyakit Dalam 2010;11(2):98.

21. Dehkordi A, Heydarnejad MS, Fatehi D. Quality of life in cancer patients undergoing chemotherapy. Oman Medical Journal 2009;24(3).

22. Sood AK, Bhatty R, Kamat AA, et al. Stress hormone mediated invasion of ovarian cancer cells. Journal of American Association for Cancer Research 2006;12(2).

23. Moreno-Smith M, Lu C, Shahzad MM, et al. dopamine block stress-mediated ovarian carcinoma growth. Clin Cancer Res. 2011;17(11):3649-59.

24. Basyar R, Sanif R. Terapi antiangiogenik pada kanker ovarium. palembang: Departemen Obstetri dan Ginekologi, Fakultas Kedokteran Universitas Sriwijaya 2014. 